\title{
Empathy and Imagination in Hannah Höch
}

\author{
Kay Tabernacle
}

The German artist Hannah Höch (1889-1978) worked in a range of media and styles during a productive life as a pioneering twentieth-century modernist, but her work is unified to an extent by her deliberate intention to affect the viewer and to change how we understand reality, and to that end, empathy plays an important part. This paper considers how empathy might function in Höch's work in relation to imagination, and also discusses an animated model of imagination, made to investigate possible architectures surrounding imagination and other associated psychic states, including empathy. The focus here is on the involvement of the body in empathy, the role played in empathy by imagination, and issues relating to body-image in Höch's work. The body is represented in much of Höch's work but it is often altered through distortions, additions or substitutions, especially in her photomontage where she cuts up and reassembles photographic reproductions of bodies. The resulting figures retain a bodily completeness but are often grotesque and sometimes disturbing. Empathy, as an ability to understand the feelings of others, or to establish an emotional rapport, involving both mind and body, as well as representations of the body; this paper aims to show that an embodied imagination is also involved.

Empathy can be understood as built into to the exercise of art in a general sense: the artist, as a communicator of information and feelings, inevitably has to imagine and understand the viewer's feelings. Both artist and viewer will often put themselves in the other's shoes in an empathetic manner. For example, in Höch's Boa Perlina (1945) a snake is drawn by collaging a photograph of a string of pearls, some feathery pieces of fabric and other elements; ${ }^{1}$ we can see this is not a snake, but understand also that it evokes the idea of a snake in Höch's imagination. And it is equally clear to the viewer that Höch expects us to understand that this image evokes the idea of a snake to her, and that she supposes that it might do the same for us. In communicating this she imbues a represented object with life, animating a collection of representations and giving them form in our imagination.

Another approach to the involvement of empathy in art is through the idea that the mind or soul and the body are at least strongly connected, if not a single entity. The brain is a bodily organ that might be considered as a potential location for the mind or soul, if it were to be found in one place and, historically, the heart has similarly been considered. Darwin discussed feelings as both emotions (psychological) and sensations (physiological) in The Expression of the Emotions in Man and Animals (1872) where sensations are described as being generated in the body. ${ }^{2}$ He quotes Norfolk from Henry VIII addressing Cardinal Wolsey:

\footnotetext{
${ }^{1}$ Hannah Höch, Hannah Höch: Picture Book, trans. Brian Currid, 2nd ed. (Berlin: Green Box, 2012).

2 'Mr Herbert Spencer (Essays, second series, 1863, p. 138) has drawn a clear distinction between emotions and sensations, the latter being "generated in our corporeal framework". He classes as feelings both emotions and sensations.' (Darwin, 1872, p. 33n) ${ }^{2}$
} 
'Some strange commotion

Is in his brain: he bites his lips and starts;

Stops on a sudden, looks upon the ground,

Then, lays his finger on his temple; straight,

Springs out into fast gait; then, stops again,

Strikes his breast hard; and anon, he casts

His eye against the moon: in most strange postures

We have seen him set himself.'

$$
\text { Hen. VIII, iii, } 2 .^{3}
$$

Through making observations Darwin connect states of mind with habitual actions, and he continues, "[t]here are other actions which are commonly performed under certain circumstances, independently of habit, and which seem to be due to imitation or some sort of sympathy. Thus persons cutting anything with a pair of scissors may be seen to move their jaws simultaneously with the blades of the scissors'. ${ }^{4}$ Here, although emotional feelings are distinct from corporeal sensation they are linked through an imitative 'sympathy'.

Taking a physiological approach to the issue of empathy in art relies on the possibility that effects may be caused by art in the body of the viewer. The viewer's physical reaction to art, such as to the figures within Höch's compositions, is addressed by Freedberg and Gallese, who propose that embodied simulations of movements or feelings are part of the aesthetic response to art. ${ }^{5}$ Freedberg and Gallese found that a physiological reaction to paintings, sculpture or other pictorial sources occurs in the form of an effect in the brain of the viewer. This is found, by Freedberg and Gallese, to particularly be the case with depictions of figures that were unbalanced, pressured, destabilised or mutilated. This could be understood as an imaginative response to the viewer's understanding, through either placing themselves empathetically in the position of the subject of the work, or by intuiting the sensations or emotions of the artist, for example, through the viewer's interpretation of the artist's gestures.

The idea that in the experience of viewing art the viewer embodies an artist's emotions through the physiological effect of the work on the viewer's brain does not assume a universality of experience. It merely suggests the possibility of there being some shared experiences or expectations among groups of people. Although empathy is not infallible, art is a form of communication and what is transmitted could include information that is empathetically understood. Imagination is at work on both sides of the communication. In the experience of making art the artist may imagine a viewer for that piece and try to use their own knowledge of their own feelings and sensations to try to predict and project how they imagine a viewer may be affected; in the experience of viewing the viewer may intentionally or unintentionally come to partly embody part of the totality of psychic states of the artist, either through the involuntary physiological effects of the work or by a more deliberate attempt on their part to empathise. The viewer might not reach the same conclusion as the artist, and there might be discrepancies between the emotions and sensations of the artist and those of the viewer, but there may also be some concordance resulting from any commonality of experience or culture between artists and viewers, and at the very least in the sense that they both inhabit a body.

\footnotetext{
${ }^{3}$ Shakespeare in Charles Darwin, The Expression of the Emotions in Man and Animals, ed. Paul Ekman, 3rd ed. (London: Harper Collins, 1998), 37. First published 1872 in the UK by John Murray.

${ }^{4}$ Darwin, The Expression of the Emotions in Man and Animals, 40.

5 David Freedberg and Vittorio Gallese, 'Motion, Emotion and Empathy in Esthetic Experience', TRENDS in Cognitive Sciences 11, no. 5 (2007): 197-203.
} 
In Höch's photomontage, representations of bodies are almost routinely dismembered and distorted. In this way Höch appears to particularly invite the kinds of responses and physiological experiences discussed above and to deliberately aim to cause experiences and sensations in the viewer. This interpretation is supported to an extent by Höch's statement, in an exhibition catalogue in 1929, that she wanted through her work to 'help people to experience a richer world', thus indicating that she understood her work as being directed at causing or altering the future experience of the viewer. ${ }^{6}$ Höch's works are experiential in the sense that they focus often on the type of bodily distortions and mutilations that tend to give rise to an experience in the viewer. The experiential pictures created by Höch have at the same time a fictional status emphasised through the use of borders, evidence of cutting (Höch's hand is always shown, and often accentuated), recognisability of the source material and the fact of its displacement. In showing the work's fictional and constructed status, Höch reveals how - in their original context - these images similarly present an artifice. As the creator, Höch needs to imagine possible responses and to predict how her own aesthetic feelings might be mirrored by the viewer. Through her use of familiar mass reproduced material, Höch exposes the evocation of emotion through pictorial image, emotion which, as a social experience, relies on shared narratives.

As well as potentially experiencing a relationship to the subject of the work, the viewer might also be considered to imaginatively embody the artist's own mental representation of their body in the process of making. To the extent that an artist's actions and processes are understood by the viewer, for example, their cutting of paper with scissors, their understanding of these processes may form part of an imaginative construction of the body-image of the artist. In The Ego and the Id (1923) Freud elaborates the structure of the mental apparatus, including its relationship to the body's surface. The body is a factor separating the Ego from the Id: '[T]he ego is ultimately derived from bodily sensations, chiefly from those springing from the surface of the body. It may thus be regarded as a mental projection of the surface of the body, besides, as we have seen above, representing the superficies of the mental apparatus. ${ }^{7}$ The mental apparatus is described by Freud as having a surface at the interface with the external world, a 'perceiving surface'. Freud describes an apparatus consisting of an Ego and an unconscious Id, 'upon whose surface rests the ego'. ' The Ego is 'first and foremost a bodily ego; it is not merely a surface entity, but is itself the projection of a surface'. ${ }^{10}$ The mental projection of the ego, a surface entity that merges into the Id, onto the surface of the body creates a body-ego that is conterminous with the body. This is experienced by an individual as a body-image.

The idea of body-image is addressed further by Paul Schilder in The Image and Appearance of the Human Body (1935), where it is described as the way our bodies are seen by ourselves, built up from the senses, from our visual view of parts of our bodies and an experience of the unity of the body. ${ }^{11}$ This body-image is constantly

\footnotetext{
${ }^{6}$ Höch translated by Juan Vicente Aliage in Aliaga, ed., Hannah Höch: Museo Nacional Centro de Arte Reina Sofía Del 20 de Enero Al 11 de Abril de 2004 (Madrid: Aldeasa, 2004), 311.

${ }^{7}$ Sigmund Freud, The Standard Edition of the Complete Psychological Works of Sigmund Freud, Volume XIX (1923-1925): The Ego and the Id and Other Works., trans. James Strachey (London: Hogarth and Institute of Psychoanalysis, 1961), 26. This footnote in the English translation is not found in the German original.

${ }^{8}$ Freud, The Ego and the Id, 19.

${ }^{9}$ Ibid, 24.

${ }^{10}$ Ibid, 26.

${ }^{11}$ Paul Schilder, The Image and Appearance of the Human Body (London: Kegan Paul, Trench, Trubner \& Co. Ltd, 1935).
} 
changing according to a person's actions, emotions and motivations and, importantly for its relationship to empathy, it is also connected to the body-images of others:

$[\mathrm{T}]$ here is from the beginning a very close connection between the body-image of ourselves and the body-images of others. We take parts of the body images of others into others, and push parts of our body-image into others. We may push our own body-images completely into others, or in some way there may be a continuous interplay between the body-images of ourselves and the persons around us. ${ }^{12}$

It may be through these connections between body-images that the actions and postures of the figures in Höch's art could affect the viewer's own body-image. Because the mental processes that take part in perception rely on the body and cannot step outside of the body, there is a theoretical boundary or event horizon around the individual that creates their point of view. Sensory input, for example the physical touch of an object, is a boundary describing experience with implications for an idea of the self. Höch's art is often firmly attached to the bodily experience, through her choice of subject, which may be an object or figure that can embody a point of view and in doing so give existence and experience a tangible form, albeit in the imagination. Schilder writes, 'strong as the tendency may be to act towards the world as we see it, there is also the tendency to unite the body-image with all other bodyimages'. In the case of viewing Höch's work, this tendency to unite our body-images is in the context of the grotesque and impossible forms that she creates. 13 The human parts used in Höch's grotesque combined forms are often the most recognisable and most involved in sensation and in reading the emotions of others - faces and eyes and the wholeness of these grotesque photomontaged figures invites a bodily understanding. In Grotesk (1963) the individual body parts become horrifying because they are de-familiarised and recombined in an unbalanced and mutilated form.14 There is little that is terrifying in the parts themselves, but the replacement of a human eye with an animal's eye, and the reduction of both figures is disturbing. These creations create complex feelings as we attempt to push our own body-images into the forms before us and see ourselves reflected back.

There is a difference between empathy, as an ability to intuit the feelings of others, putting ourselves in their shoes and imagining how they might feel, and identification, where someone positively associates themselves with another in an emotional attachment involving some level of assimilation of their characteristics. Identification can be found in those of Höch's photomontages that refer to recognisable individuals, such as Marlene Dietrich in Marlene (1930) made in the same year that the film Blue Angel was released. ${ }^{15}$ The distinct forms of response the direct physiological effect, responses to body-images, and identification with a figure within the work - may happen simultaneously. Alternatively they may alienate if at the same time as creating recognition and a positive association they cause disgust or discomfort through combining those aspects with animal forms. There might also be a sense of alienation created by the alterations made to the integrity of the body in some of the works. In works such as Flucht (Flight), from 1931, Höch combines human and animal forms, transforming them into images that we can experience bodily and which directly address our sense of self and our emotions. ${ }^{16}$ Many of Höch's figures use some constituent parts that are recognisably human and

\footnotetext{
${ }^{12}$ Schilder, The Image and Appearance of the Human Body, 235.

${ }^{13}$ Ibid, 255.

${ }^{14}$ Hannah Höch, Grotesk, Photomontage, 1963, http://tinyurl.com/nm6kbuq.

${ }^{15}$ Josef von Sternberg, Der blaue Engel, 1930.

${ }^{16}$ Hannah Höch, Flucht (Flight), Photomontage, 1931, http://www.whitechapelgallery.org/shop/images/0/image12831.jpg.
} 
in that way create a partial identification. These grotesque human-animal combinations are not simply monstrous - we still recognise something of ourselves in them.

In Siebenmeilenstiefel (Seven League Boots, 1934) Höch refers to the fairy tale boots that enable a person to take seven league strides and move quickly through the landscape. ${ }^{17}$ The magical power they contain is given through the body, which magically adapts to fit. The readers experience the shared fear of being eaten by the ogre, getting lost in the forest and being abandoned. Similarly, while looking at Höch's photomontages we can identify with the fantasy involved all the more readily because the bodily emphasis enables to work to resonate with us. We can see ourselves in the characters because there is an aspect of their make up which matches our understanding of ourselves. Höch emphasises the body through her reference to the magical boots and through her use of images of a woman's legs. Fantasy is deeply rooted in culturally shared pasts and these figures with their magical accompaniments are already common inhabitants of our minds, if that is, the viewer shares some cultural history with Höch. It is therefore possible that some viewers will readily identify with these works and extend that identification towards empathy by understanding, correctly or incorrectly, their felt responses as being those of the characters depicted, or those of the artist.

\section{Models of Imagination}

The second part of this paper is based on my practice as an artist and it investigates ways that empathy might be connected to imagination by visually modelling imagination in a short animation. ${ }^{18}$ This animated model treats a series of psychic states as being dependent on the mental production of image through imagination. It is a model of how imagination could work in any individual to transform psychic material into image-like outcomes or states and is not solely concerned with the specific example of how a viewer, an artist and a work of art interact with one another. Imagination, in this model, contributes to the total psychic material that creates our experiences. It is therefore seen as essential to the processes by which the world and its representations are understood. The image-like outcomes of the process of imagination form our everyday experience, and therefore they relate to an everyday imagination rather than a particularly creative imagination, for example one that is associated with the process of making art. In this model of the architecture of psychic states, imagination acts as a kind of transforming conduit forming the psychic material into perceptual states - organising, transforming and re-assimilating distinct but linked processes through complex and continual interactions. The indispensability of imagination to everyday experience is a feature that may allow Höch's paintings and collages to target shared and socially constructed realities in order to counter ideas of a single objective external reality. In the model (Figure 1), imagination is represented by a hollow tube, through which various psychic states may pass. The tube is a spatial analogy for an organising force that continually moves and transforms different psychic processes.

\footnotetext{
${ }^{17}$ Hannah Höch, Siebenmeilenstiefel (Seven League Boots), Photomontage, 1934, http://www.designissue.com/die-andere-seite-des-mondes-kunstlerinnen-der-avantgarde/.

${ }^{18}$ Kay Tabernacle, Models of Imagination: The Long Tube of Smarties, video (London, 2013), http://www.ucl.ac.uk/jfigs/figs-friday-forum/empathy/empathy-files/tabernacle-mov.
} 


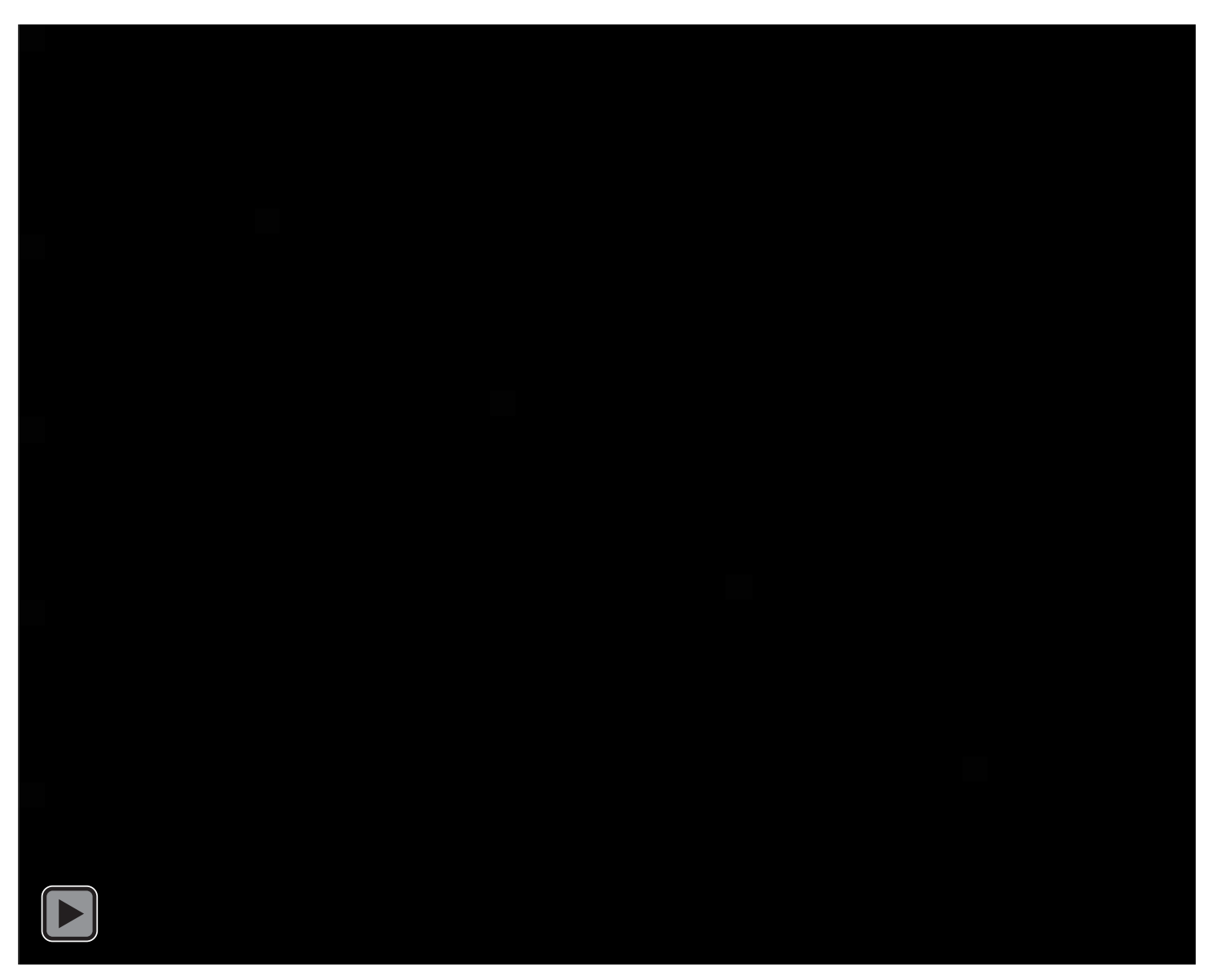

Figure 1. Kay Tabernacle, Models of Imagination: The Long Tube of Smarties, digital video (London 2013).

According to this model, psychic states are separated into two groups. At one end of the tube are psychic states that can be presented to experience through images or image-type states. These presentable states are the image outcomes of imagination, such as perception, illusion, emotion and fantasy. At the other end are those more nebulous and abstract states: cognition, intuition, sensation, memory and empathy, which are not directly presentable to experience, that is, they require translation by the imagination first. Possible image outcomes are seen at the experience end of the tube. Empathy is treated in this model as a directly unknowable psychic state that requires the process of imagination in order to become formed into an image-like outcome which can be presented to experience, perhaps as an emotion or an understanding which functions as an image, although not necessarily a visual image. The action is greatly simplified: directly unknowable psychic states such as sensation move into and through the tube where they are transformed by imagination into image states. Sensation, for example, enters the imagination tube and can be transformed into a variety of image outcomes, given here as perception and illusion. In this model, imagination is the activation mechanism that forms the psychic material into a perceptual condition. When empathy enters the tube it is transformed into emotion. Throughout the process there is a constant back-drift of psychic material from the image outcome end of the tube to be recycled. 
Höch's work exceeds superficial presentations of image and introduces deeply transformative, complex and dynamic relationships between mental images, including body-images, and a relative or subjective reality. Empathy can be involved in this linking and sharing of the material of imaginations between people. Imagination can be understood to be radicalised by Höch through her stated overarching intention to alter our assumptions about what she sees as a constructed and mythical ideal of a fully rationalised world. In a catalogue text for a group show in Berlin called Visionaries or Dreamers, Höch writes, '[n] ever has there been such an abyss between the real world and the idea as there is today. Never has this abyss been so loaded with tragic, grotesque, destructive tensions. Our previous reality lies smashed on the ground, and above it the ideal image of a new fully rationalised world still rises far and high. ${ }^{19}$ She focuses here on two separate realities and places her fantastic art at neither one side of the abyss nor the other, but demonstrating the difference between the two sides, mirroring and warning. This is a visual evocation, using spatial metaphor - the abyss, the soaring ideal above the broken reality - and a communication through art, visionary imaginative art, the art of dreamers. Other statements that Höch made about her work show that empathy is an important aspect of her intention. In a 1929 gallery text Höch explains that, '[t]he more vitality, the stronger intuition and deeper empathy underlying the artwork, the more strongly it will speak to us. ${ }^{20}$ The term empathy is used here explicitly to describe an underlying process preceding the communication and presentation of ideas. Although empathy underlies the work, it is the work that speaks to us and which we experience. If the exhibition is thought of as an analogy for the representation of mental images, the creation of art and its exhibition could be seen to function in a similar way to my proposed model for imagination: by transforming the deep feelings underlying the work into an experienceable form. In the exhibition, as in imagination, mental images are presented to experience (or to the viewer in an exhibition) and they have a history, which we may not be directly aware of. For Höch to break down and re-construct culturally shared ideas of reality relies on both imagination and empathy. Realities can be shared through social groups, involving empathy as part of the connections between people's imaginations. Höch expressed a wish to use her imagination as a bridge to change the way people engage with the world. To this end, empathy is both the hoped-for outcome and the necessary precondition, and imagination is the method.

\footnotetext{
${ }^{19}$ Peter Barth, ed., Die Fantstische Welt der Hannah Höch: Die Puppe Balsamine und der Zauberbusch (Düsseldorf: Galerie Remmert und Barth, 2008), 11-14. My translation.

20 Hannah Höch, 1929, in Ralf Burmeister and Eckhard Fürlus, eds., Hannah Höch: Eine Lebenscollage 1921-1945. Band II. Abteilung 2 (Berlin: Berlinische Galerie, 1995), 365. Translated in Burmeister and Fürlus from Dutch to German: Je mehr Lebendigkeit, je stärkere Intuition und tiefere Einfühlung dem Kunstwerk zugrunde liegen, desto stärker wird es zu uns sprechen, unabhängig davon, zu welcher Zeit oder zu welchem $>>$ ismus $<<$ es gehört.
} 


\section{Bibliography}

Aliaga, Juan, ed. Hannah Höch: Museo Nacional Centro de Arte Reina Sofía Del 20 de Enero Al 11 de Abril de 2004. Madrid: Aldeasa, 2004.

Barth, Peter, ed. Die Fantstische Welt der Hannah Höch: Die Puppe Balsamine und der Zauberbusch. Düsseldorf: Galerie Remmert und Barth, 2008.

Burmeister, Ralf, and Eckhard Fürlus, eds. Hannah Höch: Eine Lebenscollage 1921-1945. Band II. Abteilung 2. Berlin: Berlinische Galerie, 1995.

Darwin, Charles. The Expression of the Emotions in Man and Animals. Edited by Paul Ekman. 3rd ed. London: Harper Collins, 1998.

Freedberg, David, and Vittorio Gallese. 'Motion, Emotion and Empathy in Esthetic Experience'. TRENDS in Cognitive Sciences 11, no. 5 (2007): 197-203.

Freud, Sigmund. The Standard Edition of the Complete Psychological Works of Sigmund Freud, Volume XIX (1923-1925): The Ego and the Id and Other Works. Translated by James Strachey. London: Hogarth and Institute of Psychoanalysis, 1961.

Hannah Höch. Hannah Höch: Picture Book. Translated by Brian Currid. 2nd ed. Berlin: Green Box, 2012.

Schilder, Paul. The Image and Appearance of the Human Body. London: Kegan Paul, Trench, Trubner \& Co. Ltd, 1935.

Tabernacle, Kay. Models of Imagination: The Long Tube of Smarties. Video. London, 2013. http://www.ucl.ac.uk/jfigs/figs-friday-forum/empathy/empathy-files/tabernacle-mov.

Von Sternberg, Josef. Der blaue Engel, 1930. 